\title{
Comparison between surgical and percutaneous tracheostomy effects on procalcitonin kinetics in critically ill patients
}

\author{
Maria Vargas* (1), Pasquale Buonanno, Lina Giorgiano, Giovanna Sorriento, Carmine lacovazzo and Giuseppe Servillo
}

\begin{abstract}
Available evidence from randomized controlled trials including adult critically ill patients tends to show that percutaneous dilatational tracheostomy (PDT) techniques are performed faster and reduce stoma inflammation and infection but are associated with increased technical difficulties compared with surgical tracheostomy (ST). A recent meta-analysis found that PDT was superior to reduce risk of periprocedural stoma inflammation and infection compared with ST. WE found no differences in procalcitonin, C-reactive protein, SOFA, and SAPS ॥ between critically ill patients with ST or PDT.

Keywords: Tracheostomy, Procalcitonin, Infection, Sepsis, C-reactive protein, Critically ill patients
\end{abstract}

In critically ill patients, tracheostomy may be performed with surgical or percutaneous approaches [1]. Available evidence from randomized controlled trials including adult critically ill patients tends to show that percutaneous dilatational tracheostomy (PDT) techniques are performed faster and reduce stoma inflammation and infection but are associated with increased technical difficulties compared with surgical tracheostomy $(\mathrm{ST})[2,3]$. Overall complication rates are similar for PDT and ST, but with an increased incidence of infection for ST [4]. A recent meta-analysis found that PDT was superior to reduce risk of periprocedural stoma inflammation and infection compared with ST [4]. In the elderly population, fever is the most common postoperative complication after ST (42\%), followed by wound infection (4\%) [4]. Procalcitonin (PCT) may be a reliable biomarker to predict infectious or septic complications related to tracheostomy performed in the ICU [5]. A retrospective study reported that PCT was not elevated after ST performed in the ICU [5]. However, little is known about procalcitonin kinetics after ST or PDT in critically ill patients, since ST seems to be associated with an increased incidence of infection in this cohort of patients.

We screened 122 critically ill patients for tracheostomy, of which 12 received ST and 13 received PDT (Table 1). We found no difference in the baseline characteristics of patients between the two groups. Upper respiratory, blood, and urinary cultures performed 3 days before the procedure were negative for each patient. We found no difference between PCT, C-reactive protein (CRP), Sepsis Organ Failure Assessment (SOFA) score, and Simplified Acute Physiology Score (SAPS) II between the groups (all $p>0.05$; Fig. 1). Upper respiratory, blood, and urinary cultures performed 3 days after the procedure were negative for each patient. The trends of PCT levels over time did not correlate with the trend of CRP levels in each group (ST group, $r=0.074, p=0.671$; $\mathrm{r}^{2}=0.139, p=0.425$; PDT group, $r=-0.169, p=0.297$; $\left.r^{2}=-0.063, p=0.697\right)$.

To our knowledge this is the first report evaluating the kinetics of different biomarkers of infection in a cohort of tracheostomized patients. According to the literature, ST was associated with an increased risk of infections [4, 5]. We found that the biomarkers of infection were not different between the ST and PDT groups and remained stable in the first week after the procedure. According to these data, ST may not increase the risk of infections and sepsis in critically ill patients.

* Correspondence: vargas.maria82@gmail.com

Department of Neurosciences, Reproductive and Odontostomatological

Sciences, University of Naples "Federico II", via pansini, Naples, Italy

(c) The Author(s). 2018 Open Access This article is distributed under the terms of the Creative Commons Attribution 4.0 International License (http://creativecommons.org/licenses/by/4.0/), which permits unrestricted use, distribution, and reproduction in any medium, provided you give appropriate credit to the original author(s) and the source, provide a link to the Creative Commons license, and indicate if changes were made. The Creative Commons Public Domain Dedication waiver (http://creativecommons.org/publicdomain/zero/1.0/) applies to the data made available in this article, unless otherwise stated. 


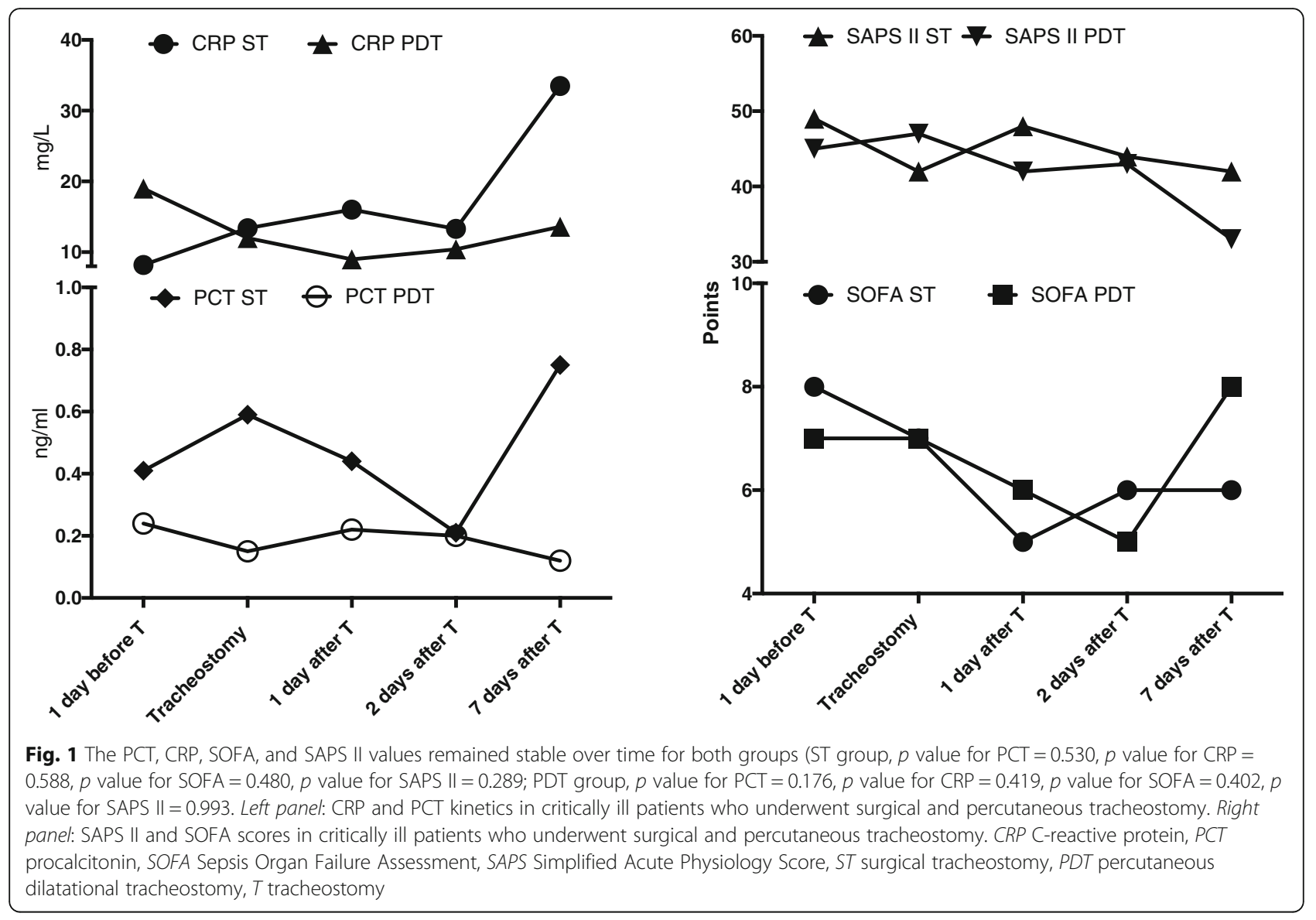

Table 1 Characteristics of included patients

\begin{tabular}{|c|c|c|c|}
\hline & $\begin{array}{l}\text { Surgical } \\
\text { tracheostomy } \\
(n=12)\end{array}$ & $\begin{array}{l}\text { Percutaneous } \\
\text { dilatational } \\
\text { tracheostomy } \\
(n=13)\end{array}$ & $p$ \\
\hline Age (years) & $60 \pm 10$ & $56 \pm 10$ & 0.778 \\
\hline Gender (M/F) & $8 / 5$ & $7 / 6$ & 0.539 \\
\hline BMI & $20 \pm 10$ & $20.6 \pm 8$ & 0.345 \\
\hline $\begin{array}{l}\text { Reason for ICU } \\
\text { admission (N) }\end{array}$ & & & 0.678 \\
\hline - Medical & 7 & 6 & \\
\hline - Trauma & 3 & 4 & \\
\hline - Surgical & 2 & 3 & \\
\hline $\begin{array}{l}\text { Duration of } \\
\text { endotracheal } \\
\text { intubation before T }\end{array}$ & $15 \pm 3$ & $13 \pm 5$ & 0.257 \\
\hline $\begin{array}{l}\text { Variables during } \\
\text { procedure }(\mathrm{N})\end{array}$ & & & 0.675 \\
\hline - Antibiotics & 3 & 4 & \\
\hline - Corticosteroid & 4 & 3 & \\
\hline - Fever $\left(>37^{\circ}\right)$ & 0 & 0 & \\
\hline
\end{tabular}

\section{Abbreviations}

CRP: C-reactive protein; PCT: Procalcitonin; PDT: Percutaneous dilatational tracheostomy; SAPS II: Simplified Acute Physiology Score II; SOFA: Sepsis Organ Failure Assessment; ST: Surgical tracheostomy

\section{Acknowledgements}

Not applicable.

\section{Funding}

No funding.

\section{Availability of data and materials}

Not applicable.

\section{Authors' contributions}

$\mathrm{MV}, \mathrm{PB}, \mathrm{LG}, \mathrm{GS}, \mathrm{Cl}, \mathrm{FA}$, and $\mathrm{GS}$ analyzed and interpreted the data, wrote the paper, and approved the manuscript.

\section{Ethics approval and consent to participate}

University of Naples "Federico II" - protocol number132/17.

\section{Consent for publication}

Not applicable.

\section{Competing interests}

The authors declare that they have no competing interests.

\section{Publisher's Note}

Springer Nature remains neutral with regard to jurisdictional claims in published maps and institutional affiliations. 
Received: 24 September 2018 Accepted: 18 October 2018

Published online: 14 November 2018

\section{References}

1. Vargas M, Pelosi P, Servillo G. Percutaneous tracheostomy: it's time for a shared approach! Crit Care. 2014;8:448

2. Vargas M, Sutherasan Y, Antonelli M, Brunetti I, Corcione A, Laffey JG, Putensen C, Servillo G, Pelosi P. Tracheootmy procedures in the intensive care unit: an international survey. Crit Care. 2015;19:291-301.

3. Vargas M, Servillo G, Arditi E, et al. Tracheostomy in Intensive Care Unit: a national survey in Italy. Minerva Anestesiol. 2013;79:156-64.

4. Putensen C, Theuerkauf N, Guenther U, et al. Percutaneous and surgical tracheostomy in critically ill adult patients: a meta-analysis. Crit Care. 2014; 18:544.

5. Sato K, Okajima M, Noda T, et al. Impact of bedside tracheostomy on procalcitonin kinetics in critically ill patients. J Intensive Care Med. 2017. https://doi.org/10.1177/0885066617696845 [Epub ahead of print]. 